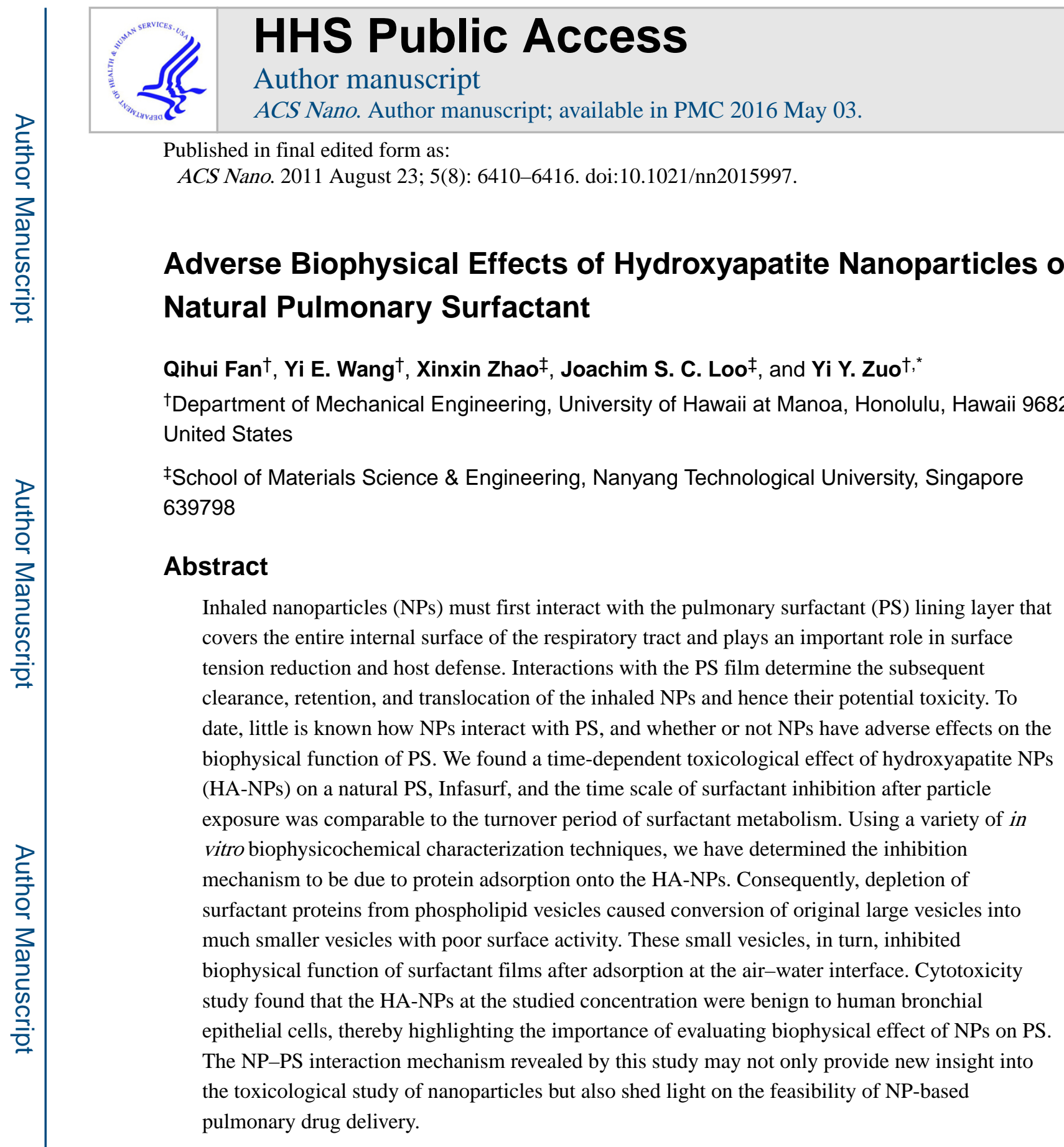

\title{
Keywords
}

nanotoxicology; nanoparticle; pulmonary surfactant; surfactant inhibition; surface tension

Due to their small size, inhaled nanoparticles (NPs) can have a high deposition rate in the alveolar region of the lung. ${ }^{1-3}$ Because of their large surface area-to-volume ratio and hence a high inflammatory potential per given mass, inhaled NPs can induce pulmonary

\footnotetext{
*Address correspondence to yzuo@ hawaii.edu.

Supporting Information Available: Supplemental experimental results. This material is available free of charge via the Internet at http://pubs.acs.org.
} 
inflammation, oxidative stress, lipid peroxidation, fibrotic reaction, and adverse immune response in the respiratory system. ${ }^{4-8}$

Once reaching the alveolar region, inhaled NPs must first interact with the pulmonary surfactant lining layer of alveoli. ${ }^{9,10}$ Pulmonary surfactant (PS) is a phospholipid-protein mixture synthesized by type II alveolar epithelial cells. It covers the entire internal surface of the respiratory tract as a thin film and plays a crucial role in surface tension reduction and host defense. ${ }^{11,12}$ By reducing alveolar surface tension to near-zero, the PS film stabilizes alveoli against collapse, thereby maintaining a large surface area for gas exchange.

Interaction with the PS film determines the subsequent clearance, retention, and translocation of inhaled NPs and hence their potential toxicity, such as interference with PS metabolism, interaction with lung epithelial cells, alveolar macrophages and neutrophils, and translocation to the bloodstream and other organs. ${ }^{9,10}$ To date, however, little is known how NPs interact with PS, and whether or not NPs have adverse effects on the biophysical function (i.e., surface tension reduction) of PS. ${ }^{13-19}$

In this paper, we used a variety of biophysicochemical characterization techniques to study the molecular mechanism of in vitro interaction between a natural PS, Infasurf, and engineered hydroxyapatite NPs (HA-NPs) of spherical shape with the diameter of $\sim 90 \mathrm{~nm}$. Infasurf (ONY, Inc., Amherst, NY) is a modified natural surfactant prepared from lung lavage of newborn calves by centrifugation and organic solvent extraction. Infasurf contains all hydrophobic components of natural surfactant, including $90 \mathrm{wt} \%$ phospholipids, 5-8\% neutral lipids (mainly cholesterol), and $2 \%$ hydrophobic surfactant proteins (SP-B and SPC). ${ }^{20,21}$ Hydroxyapatite is the main mineral component of bones and teeth. Due to its ideal biocompatibility and biodegradability, nanoparticles made of hydroxyapatite have been widely used for biomedical applications, such as orthopedic implants and drug delivery. ${ }^{22-24}$ We have also studied the effect of HA-NPs on viability of human bronchial epithelial BEAS-2B cells. The aim of this study is to explore the potential adverse biophysical effect of HA-NPs on natural PS, while comparing with their potential cytotoxicity to bronchial epithelial cells.

\section{RESULTS AND DISCUSSION}

\section{Effects on Surface Activity and Lateral Film Structure}

We first investigated the effect of HA-NPs on surface activity and interfacial structure of Infasurf films using Langmuir balance and atomic force microscopy (AFM). Figure 1a shows the time-dependent compression isotherms of Infasurf before and after exposure to 1 wt $\%$ HA-NPs. The 1 wt $\%$ HA-NPs are equivalent to a NP concentration of $50 \mu \mathrm{g} / \mathrm{mL}$, corresponding to the lower end of the NP concentration tested in previous studies. ${ }^{14-16}$ It is found that there was a significant time-dependent deterioration of Infasurf after exposure to the HA-NPs. Right after exposure $(0 \mathrm{~h})$, there was no sign of surfactant inhibition. However, after $1 \mathrm{~h}$, the compressibility of Infasurf films significantly increased, that is, more area reduction required to increasing surface pressure $\pi$ (equal to decreasing surface tension), thus indicating surfactant inhibition. Such inhibition effects progressed with time and somewhat reached equilibrium after $7 \mathrm{~h}$. Further increasing incubation time (up to 5 days) 
did not significantly vary the compression isotherms. Control experiments with pure Infasurf showed that this surfactant preparation was very stable in air (see Supporting Information). Hence, the surfactant inhibition shown in Figure 1a can only be due to exposure to the HANPs. Note that the estimated turnover period of PS in vivo ranges from 4 to $11 \mathrm{~h} .{ }^{11,12}$ Therefore, the kinetic inhibitory effect of $1 \%$ HA-NPs on Infasurf can be indeed physiologically relevant.

Panels b-e of Figure 1 compare the lateral structure of Infasurf with and without HA-NPs at two characteristic $\pi, 40$ and $50 \mathrm{mN} / \mathrm{m}$, respectively. (See Supporting Information for comparison at additional $\pi$.) First of all, neither individual NPs nor particle agglomerations were detected at the interface by AFM at any $\pi$. This AFM observation indicates that the HA-NPs readily penetrated the PS film at the air-water interface, consistent with the hydrophilicity of these NPs. Although penetrating the interfacial monolayer, the HA-NPs altered both the compression isotherms and lateral structure of the Infasurf films. Compared to pure Infasurf, AFM detected a substantially smaller amount of lipid domains with much smaller sizes at the same $\pi$ of $40 \mathrm{mN} / \mathrm{m}$ (Figure $1 \mathrm{~b}$ vs $1 \mathrm{~d}$ ). Moreover, we found that the HANPs altered the monolayer-to-multilayer transition of Infasurf, as indicated by variation of multilayer structure at $50 \mathrm{mN} / \mathrm{m}$ (Figure 1c vs 1e). Without the NPs, Infasurf films at the physiologically relevant $\pi$ (i.e., $50 \mathrm{mN} / \mathrm{m}$ and higher ${ }^{11,25}$ ) assume a conformation of uniformly distributed fluid phospholipid multilayers with embedded condensed phospholipid domains (as "holes") at the interfacial monolayer. ${ }^{21,25}$ This matrix structure of multilayers forms a surfactant reservoir that stores PS upon film compression and releases PS upon subsequent film expansion, thus increasing film stability. ${ }^{11,12}$ However, after exposure to HA-NPs, the matrix structure disappeared and the multilayers were formed as isolated crystalline folds along the direction of lateral compression, thus causing surfactant inhibition.

\section{Effects on Vesicle Size and Ultrastructure}

Since the HA-NPs readily penetrated the PS film, we ruled out the possibility that direct PSNP interaction at the air-water interface is responsible for the inhibition mechanism of Infasurf. We then scrutinized the effect of HA-NPs on the phospholipid vesicles in the bulk phase using particle sizer and transmission electron microscopy (TEM). Figure $2 \mathrm{a}$ shows the time-dependent measurement of vesicle size of Infasurf with and without exposure to $1 \%$ HA-NPs. It is found that pure Infasurf featured a large vesicle size about $15 \mu \mathrm{m}$, and the size did not significantly vary for $3 \mathrm{~h}$. In contrast, after exposure to HA-NPs, Infasurf showed a significant time-dependent decease in vesicle size. Right after exposure to the NPs (i.e., at 0 h), there was no significant difference in the vesicle size compared to pure Infasurf.

However, after $1 \mathrm{~h}$ exposure, the vesicle size decreased dramatically from $\sim 15$ to $\sim 2 \mu \mathrm{m}$. It continuously dropped to $\sim 0.5 \mu \mathrm{m}$ after $3 \mathrm{~h}$ exposure.

In addition to the vesicle size measurement, we have studied the ultrastructure of Infasurf in the bulk phase with and without exposure to the HA-NPs. As shown in Figure 2b, pure Infasurf showed a large multilamellar vesicular structure with a size comparable to that measured by the particle sizer. (Note that the fractures on the vesicle surface are due to rupture during the fixation procedure of TEM.) However, after exposure to the HA-NPs 
(Figure $2 \mathrm{c}$ ) for $3 \mathrm{~h}$, the large multilamellar vesicles were dissociated into much smaller unilamellar vesicles (Figure 2d). The surfactant ultrastructure detected by TEM is consistent with the particle sizer measurements. A high-resolution TEM image (Figure 2e) shows clearly that the HA-NPs bound to the surfactant vesicles and likely penetrated into the vesicles.

To better understand the interaction between HA-NPs and surfactant vesicles of Infasurf, we have measured the zeta-potential of HA-NPs, pure Infasurf, and Infasurf mixed with 1\% HA-NPs. Values of zeta-potential of the above three samples are $-10.0 \pm 1.8,4.7 \pm 2.9$, and $-4.2 \pm 1.7 \mathrm{mV}$, respectively. The zeta-potential of HA-NPs is in good agreement with previous measurements. ${ }^{26,27}$ The positive zeta-potential of surfactant vesicles is likely due to the two surfactant proteins in Infasurf, that is, SP-B and SP-C, both carrying net positive charges. ${ }^{28,29}$ Hence, these zeta-potential data may indicate that the interaction between HANPs and Infasurf (or, more precisely, surfactant proteins in Infasurf) is electrostatic in nature.

It is known that morphological transformation from large aggregates (LAs) to small aggregates (SAs) is a significant indication of surfactant degradation. ${ }^{30,31}$ While the LAs represent the surface-active components of PS, the SAs show slow adsorption and inability of reaching low surface tensions. ${ }^{30,31}$ The poor surface activity of SAs is mainly due to deficiency and/or dysfunction of surfactant proteins, especially SP-B and SP-C, which are transmembrane proteins that may induce vesicle fusion to promote formation of large and surface-active vesicles. ${ }^{30,31}$ Therefore, the significant reduction of vesicle size after exposure to HA-NPs led us to the hypothesis of protein adsorption to the HA-NP surface, thus depleting surfactant proteins from these vesicles.

\section{Effects on Surfactant Protein Adsorption}

We tested this hypothesis by quantifying surfactant proteins using BCA assays. We first centrifuged the samples and measured protein concentrations in both the pellets and the supernatant. The centrifugation rate was carefully set to be $25000 \mathrm{~g}$ (for $15 \mathrm{~min}$ ), which spun down the vesicles but not free NPs. Because the HA-NPs bound to surfactant vesicles (Figure 2e), we sonicated some samples vigorously to separate these NPs from surfactant vesicles. Since the procedure of sonication tends to reduce the size of surfactant vesicles and hence affects protein contents after centrifugation, we used pure Infasurf as controls for these sonicated samples. Figure 3 shows protein concentrations in Infasurf with and without $1 \%$ HA-NPs and with and without the sonication procedure. First of all, it is found that the sum of protein concentrations in the pellets and the supernatant for all four measurement groups was approximately the same and equal to $\sim 800 \mu \mathrm{g} / \mathrm{mL}$. This value is in good agreement with the literature value of surfactant protein (SP-B and SP-C) concentration in Infasurf, ${ }^{20}$ thus proving the accuracy of our BCA assays. Second, without sonication, the protein concentration in the supernatant of the mixture of Infasurf and HA-NPs was very low and lower than that in the pure Infasurf. However, after sonication, the protein concentration in the supernatant of the NP-containing mixture significantly increased 6-fold compared to the nonsonication group and became higher than that in the pure Infasurf with sonication. Although the procedure of sonication increased the protein concentration in the supernatant of pure Infasurf by approximately 50\% due to reduced surfactant vesicle size, 
sonication alone was not sufficient to explain the 6-fold increase of protein in the NPcontaining mixture. Therefore, these data indicate that the HA-NPs released to the supernatant by sonication carried a significant amount of adsorbed proteins. This result is not unexpected as it is well-known that HA has high affinity for proteins, and consequently, HA-NPs have been well studied as a vehicle for protein delivery. ${ }^{24,32,33}$ It should be noted that even with sonication there was only one-eighth of total surfactant proteins in the supernatant. This is likely due to the fact that the sonication procedure only released a portion of HA-NPs, and there was a significant amount of protein-coated NPs still associated with the surfactant vesicles in the pellets.

\section{Effects on Human Bronchial Epithelial Cell Viability}

We further tested the potential cytotoxicity of the HA-NPs on human bronchial epithelial BEAS-2B cells using two different assays, that is, the PicoGreen and WST-8. After $24 \mathrm{~h}$ exposure to HA-NPs of various concentrations (30,100, and $300 \mu \mathrm{g} / \mathrm{mL}$ ), the amount of double-stranded DNA (dsDNA) and metabolic activity were measured with PicoGreen and WST-8 assays, respectively. Results from both assays (Figure 4) show that HA-NPs up to $100 \mu \mathrm{g} / \mathrm{mL}$ did not elicit any significant toxicological effects on BEAS-2B cells, consistent with our previous finding. ${ }^{27}$ With increasing HA-NP concentration to $300 \mu \mathrm{g} / \mathrm{mL}$, cell viability measured by both assays decreased (73\% by PicoGreen and $88 \%$ by WST- 8 ), indicating a slight increase of cytotoxicity at this high particle concentration. The $1 \mathrm{wt} \%$ HA-NPs used in our biophysical studies correspond to a NP concentration of $50 \mu \mathrm{g} / \mathrm{mL}$. These cell viability measurements therefore suggest that HA-NPs at the studied concentration are noncytotoxic to bronchial epithelial cells, although they do have significant adverse biophysical effects on pulmonary surfactant.

A variety of cells participate in the pulmonary immune response, and the relative contribution of difference cells varies with different diseases and the degree of inflammation. ${ }^{34}$ It has been reported that inhaled NPs may directly cause acute lung injury (ALI) in vivo ${ }^{35}$ or worsen the progression of ALI in animal models. ${ }^{36}$ In ALI, the number of cells isolated by lavage increased dramatically with a majority of cells being neutrophils, which are the earliest immune cells recruited to the site of injury or inflammation. ${ }^{37}$

Quintero and Wright found that in ALI the combination of activated macrophages and large numbers of neutrophils recruited to the lung could lead to 7 times more phospholipid clearance than the normal lung. ${ }^{38}$ This increased clearance of surfactant phospholipids could, over time, lead to smaller pools of functional surfactant and hence impaired biophysical properties in reducing the alveolar surface tension. ${ }^{38}$ Together with potential surfactant inactivation due to alveolar influx of serum proteins (as a consequence of increased permeability of the alveolocapillary barrier ${ }^{11}$ ) and direct adverse biophysical effects caused by engineered NPs observed in the present study, all of these surfactantrelated mechanisms may contribute to the pathophysiology of ALI due to NP inhalation.

In conclusion, we found that HA-NPs ( $\sim 90 \mathrm{~nm})$ at a low concentration (1 wt \%), though benign to human bronchial epithelial BEAS-2B cells, were able to inhibit the biophysical function of a natural PS, Infasurf. Surfactant inhibition due to the HA-NPs was kinetically dependent, and the time scale was comparable to the turnover period of surfactant 
metabolism. Given the importance of PS in maintaining normal respiratory mechanics, this study suggests that the conventional cytotoxicological test alone may not be sufficient in evaluating the toxicological effect of inhaled NPs. The inhibition mechanism was found not to be due to direct particle interference at the air-water interface, as previously speculated. Rather, the surfactant inhibition was due to adsorption of surfactant proteins onto the HANPs. Consequently, depletion of proteins from surfactant vesicles caused conversion of original large phospholipid vesicles into much smaller vesicles. These small vesicles, in turn, inhibited surface activity of surfactant films after adsorption. The NP-PS interaction mechanism revealed by this study may not only provide new insight into the toxicological study of nanoparticles but also shed light on the feasibility of NP-based pulmonary drug delivery.

\section{MATERIALS AND METHODS}

\section{Pulmonary Surfactant}

Infasurf (ONY Inc., Amherst, NY) is a clinical pulmonary surfactant (PS) and is commercially available. Infasurf was stored frozen in sterilized vials with an initial concentration of $35 \mathrm{mg}$ total phospholipids per milliliter. On the day of experiment, it was diluted to $5 \mathrm{mg} / \mathrm{mL}$ by a saline buffer of $0.9 \% \mathrm{NaCl}, 1.5 \mathrm{mM} \mathrm{CaCl}_{2}$, and $2.5 \mathrm{mM}$ HEPES, adjusted to $\mathrm{pH}$ 7.0. The water used was Milli-Q ultrapure water (Millipore, Billerica, MA) which has a resistivity higher than $18 \mathrm{M} \Omega \cdot \mathrm{cm}$ at room temperature.

\section{Nanoparticles}

Hydroxyapatite nanoparticles (HA-NPs) were synthesized by a technique reported previously. ${ }^{39}$ In summary, calcium pantothenate $\left(\mathrm{C}_{18} \mathrm{H}_{32} \mathrm{CaN}_{2} \mathrm{O}_{10} \cdot x \mathrm{H}_{2} \mathrm{O}\right)(0.01 \mathrm{~mol})$ was dissolved in $10 \mathrm{~g}$ of water solution, and the $\mathrm{pH}$ of this solution was adjusted to $\mathrm{pH} 1 \mathrm{using}$ droplets of concentrated hydrochloric acid $(\mathrm{HCl})$. Potassium phosphate $\left(\mathrm{K}_{2} \mathrm{HPO}_{4} \cdot 3 \mathrm{H}_{2} \mathrm{O}\right)$ solution $(0.006 \mathrm{~mol})$ was then slowly added to this acidic solution with stirring. The final solution was slowly adjusted to an alkaline $\mathrm{pH}(\mathrm{pH}=12)$ using droplets of concentrated $\mathrm{NaOH}$ solution and further stirred for $24 \mathrm{~h}$. Finally, the reaction mixture was centrifuged and washed repeatedly five times using deionized water. The HA-NPs were subsequently characterized for particle size and shape, hydrodynamic size, and specific surface area.

To evaluate particle size and shape, the dried powders of HA-NPs were observed under TEM (JEOL 2010 TEM; JEOL Ltd., Tokyo, Japan) at an accelerating voltage of $200 \mathrm{kV}$ with a $\mathrm{LaB}_{6}$ cathode. Samples were prepared by mixing a small quantity of HA-NPs in ethanol with 10 min of ultrasonic treatment, before dropping onto carbon-coated copper grids. Particle size was measured $(n=200)$ using the ImageJ software and was found to be $\sim 67.8$ $\mathrm{nm}( \pm 22.5 \mathrm{~nm})$. The colloidal size measured from DLS was $\sim 93 \mathrm{~nm}$ using a Zeta Nanosizer (Malvern Co., UK). Specific surface area was determined from the Brunauer-Emmett-Teller (BET) method using the Micromeritics surface area analyzer (ASAP 2000, USA) and was found to be $\sim 32.2 \mathrm{~m}^{2} / \mathrm{g}$. This BET surface area is in good agreement with our previous publication, in which no surfactant was used in synthesizing the HA-NPs, ${ }^{23}$ but less than the high surface area nanoparticles synthesized with surfactant. ${ }^{39}$ 


\section{Langmuir-Blodgett Trough}

Spread, compression, and Langmuir-Blodgett (LB) transfer of surfactant films were conducted with a LB trough (KSV Nima, Coventry, UK) at room temperature $\left(20 \pm 1{ }^{\circ} \mathrm{C}\right)$. This trough is equipped with two Delrin barriers to minimize film leakage. The trough contains a $\sim 160 \mathrm{~mL}$ subphase and has an operational surface area of $266 \mathrm{~cm}^{2}$.

Surfactant monolayers were prepared by spreading Infasurf on ultrapure water. Our previous studies showed that spreading on buffer instead of pure water caused no detectable differences in the compression isotherms and lateral structures of the surfactant films. ${ }^{40,41}$ Films were spread by depositing tiny droplets of samples uniformly throughout the air-water interface using a $10 \mu \mathrm{L}$ microsyringe. The initial amount of spreading, with or without $1 \%$ HA-NPs, was controlled to be $\sim 20 \mu \mathrm{L}$. After spreading, all films were left undisturbed for 10 min to allow equilibrium.

The spread films were compressed at a rate of $20 \mathrm{~cm}^{2} / \mathrm{min}$, namely, $0.1 \%$ initial surface area per second. During compression, surface pressure-area $(\pi-\mathrm{A})$ isotherms were recorded. The film surface area $\left(\mathrm{cm}^{2}\right)$ rather than the absolute molecular area $\left(\AA^{2} /\right.$ molecule $)$ was used to express the compression isotherms. This is due to the difficulty of controlling the exact amount of surfactant molecules at the air-water interface since the films were spread from aqueous media.

For atomic force microscopy imaging, Infasurf films at the air-water interface were transferred to the surface of freshly cleaved mica using the LB technique. Surfactant films at controlled constant $\pi$ were deposited onto the mica surface by elevating the previously submerged mica vertically through the air-water interface at a rate of $1 \mathrm{~mm} / \mathrm{min}$. Deposited films were scanned by AFM within $2 \mathrm{~h}$ of deposition. Aging of LB films in air over this time period is considered to have negligible effects on film structure. ${ }^{40,41}$

AFM

Topographical images were obtained using an Innova AFM (Bruker, Santa Barbara, CA). Samples were scanned in air. Each sample was characterized at multiple locations with various scan areas to ensure the detection of representative structures. Both contact mode and tapping mode were used. The different scan modes gave equivalent results. A silicon nitride cantilever with a spring constant of $0.12 \mathrm{~N} / \mathrm{m}$ and a nominal tip radius of $2 \mathrm{~nm}$ was used in contact mode, and a silicon probe with a resonance frequency of $300 \mathrm{kHz}$ and a spring constant of $40 \mathrm{~N} / \mathrm{m}$ was used in tapping mode. Scan parameters, such as the deflection set point, gains, and scan rate, were optimized with the lowest force and highest gains possible to minimize tip artifact. Analysis of the AFM images was performed using Nanoscope software (version 7.30).

\section{TEM}

Ultrastructure of surfactant vesicles, with and without $1 \mathrm{wt} \%$ HA-NPs, was studied using a Zeiss LEO 912 energy-filtering TEM operated at $100 \mathrm{kV}$. Samples were prepared with the following fixation procedure. Sample pellets were fixed at room temperature with $2.5 \%$ glutaraldehyde in $0.1 \mathrm{M}$ sodium cacodylate buffer with $2 \mathrm{mM} \mathrm{CaCl}_{2}$ at $\mathrm{pH} 7.4$, washed 
twice with $0.1 \mathrm{M}$ cacodylate buffer, and then postfixed with $1 \%$ osmium tetroxide in the same buffer. After dehydration in a graded acetone series, samples were infiltrated and embedded in LX-112 epoxy resin. For TEM observation, sections of $\sim 60 \mathrm{~nm}$ thick were obtained by ultramicrotomy with a diamond knife.

\section{Particle Sizer and Zeta-Potential Analyzer}

Lipid vesicle size of Infasurf, with and without $1 \mathrm{wt} \% \mathrm{HA}-\mathrm{NPs}$, was determined using a Brookhaven 90Plus/BI-MAS particle sizer (Holtsville, NY). Infasurf was diluted to 0.1 $\mathrm{mg} / \mathrm{mL}$ using a saline buffer, and the vesicle size was measured every $1 \mathrm{~h}$ for $3 \mathrm{~h}$. Zetapotentials of HA-NPs, pure Infasurf, and Infasurf mixed with 1 wt \% HA-NPs were measured using a Brookhaven Zetaplus zeta-potential analyzer.

\section{BCA Protein Assay}

The BCA protein assay was conducted using a BCA assay kit (Pierce Biotechnology, Rockford, IL) following the manufacturer's instruction.

\section{Cytotoxicity Assay}

DNA content was measured using the PicoGreen assay, which quantifies the amount of double-stranded DNA (dsDNA) in a culture. Cell metabolic activity was studied by the WST-8 assay (Dojindo Molecular Laboratories Inc., Kumamoto, Japan). Cells were seeded on 24-well plates at a density of $5-10^{4}$ cells/well. After overnight incubation, culture media from the wells was replaced with fresh aliquots of complete media containing HA-NPs in concentrations of 30,100 , and $300 \mu \mathrm{g} / \mathrm{mL}$ ( $1 \mathrm{wt} \%=50 \mu \mathrm{g} / \mathrm{mL}$ ). After $24 \mathrm{~h}$ exposure, media containing HA-NPs were removed and the cells were washed three times in PBS to remove freely suspended nanoparticles. Cell culture medium was utilized as negative control.

For PicoGreen assay, Triton X-100 solution $(0.1 \% \mathrm{v} / \mathrm{v})$ was added into each well to lyse the adherent cells with agitation. Subsequently, $100 \mu \mathrm{L}$ aliquots of the cell lysate were transferred into a 96-well black plate. PicoGreen working solution $(100 \mu \mathrm{L})$ was then added into each well and mixed with the cell lysate for $5 \mathrm{~min}$. Fluorescent intensity was measured using an Infinite200 microplate reader with excitation/emission wavelength of 480/520 nm (Tecan Inc., Maennedorf, Switzerland).

For WST-8 assay, WST-8 reagent was diluted (1:10) in complete media, added to each well, and incubated for $3 \mathrm{~h}$ at $37^{\circ} \mathrm{C}$ and $5 \% \mathrm{CO}_{2}$. Subsequently, $100 \mu \mathrm{L}$ aliquots of the reaction mixture were then transferred onto a fresh 96-well plate, and absorbance readings were measured at $450 \mathrm{~nm}$ using an Infinite200 microplate reader.

\section{Statistical Analysis}

All quantitative experiments were conducted at least in triplicates and the data expressed as means \pm standard deviation (SD). Statistical analyses were carried out using one-way ANOVA, followed by Tukey's HSD posthoc test on SPSS version 11.5. Differences were considered statistically significant when the $p$ value was less than 0.05 . 


\section{Supplementary Material}

Refer to Web version on PubMed Central for supplementary material.

\section{Acknowledgments}

The authors thank Dr. Walter Klein at ONY Inc. for donation of Infasurf samples. We thank Tina M. Weatherby at the Biological Electron Microscope Facility for assistance in TEM measurements, Dr. Paul Patek, Dr. Tao Yan, and Joseph Lichwa for using common facilities. We also thank Drs. Lin Zhao and Fred Possmayer for insightful discussion of protein assays. This work was supported by startup grants from the University of Hawaii at Manoa (Y.Y.Z.) and the Leahi Fund to Treat \& Prevent Pulmonary Disease (44936) from the Hawaii Community Foundation (Y.Y.Z.).

\section{REFERENCES AND NOTES}

1. Oberdorster G, Oberdorster E, Oberdorster J. Nanotoxicology: An Emerging Discipline Evolving from Studies of Ultrafine Particles. Environ Health Persp. 2005; 113:823-839.

2. Muhlfeld C, Rothen-Rutishauser B, Blank F, Vanhecke D, Ochs M, Gehr P. Interactions of Nanoparticles with Pulmonary Structures and Cellular Responses. Am J Physiol. 2008; 294:L817L829.

3. Card JW, Zeldin DC, Bonner JC, Nestmann ER. Pulmonary Applications and Toxicity of Engineered Nanoparticles. Am J Physiol. 2008; 295:L400-L411.

4. Nel AE, Madler L, Velegol D, Xia T, Hoek EMV, Somasundaran P, Klaessig F, Castranova V, Thompson M. Understanding Biophysicochemical Interactions at the Nano-Bio Interface. Nat Mater. 2009; 8:543-557. [PubMed: 19525947]

5. Poland CA, Duffin R, Kinloch I, Maynard A, Wallace WA, Seaton A, Stone V, Brown S, Macnee W, Donaldson K. Carbon Nanotubes Introduced into the Abdominal Cavity of Mice Show Asbestoslike Pathogenicity in a Pilot Study. Nat Nanotechnol. 2008; 3:423-428. [PubMed: 18654567]

6. Ryman-Rasmussen JP, Cesta MF, Brody AR, Shipley-Phillips JK, Everitt JI, Tewksbury EW, Moss OR, Wong BA, Dodd DE, Andersen ME, et al. Inhaled Carbon Nanotubes Reach the Subpleural Tissue in Mice. Nat Nanotechnol. 2009; 4:747-751. [PubMed: 19893520]

7. Bonner JC. Lung Fibrotic Responses to Particle Exposure. Toxicol Pathol. 2007; 35:148-153. [PubMed: 17325983]

8. Braydich-Stolle LK, Speshock JL, Castle A, Smith M, Murdock RC, Hussain SM. Nanosized Aluminum Altered Immune Function. ACS Nano. 2010; 4:3661-3670. [PubMed: 20593840]

9. Schleh C, Hohlfeld JM. Interaction of Nanoparticles with the Pulmonary Surfactant System. Inhal Toxicol. 2009; 21:97-103. [PubMed: 19558240]

10. Peters A, Veronesi B, Calderon-Garciduenas L, Gehr P, Chen LC, Geiser M, Reed W, RothenRutishauser B, Schurch S, Schulz H. Translocation and Potential Neurological Effects of Fine and Ultrafine Particles a Critical Update. Part Fibre Toxicol. 2006; 3:13. [PubMed: 16961926]

11. Zuo YY, Veldhuizen RA, Neumann AW, Petersen NO, Possmayer F. Current Perspectives in Pulmonary Surfactant-Inhibition, Enhancement and Evaluation. Biochim Biophys Acta. 2008; 1778:1947-1977. [PubMed: 18433715]

12. Possmayer F, Hall SB, Haller T, Petersen NO, Zuo YY, Bernardino de la Serna J, Postle AD, Veldhuizen RAW, Orgeig S. Recent Advances in Alveolar Biology: Some New Looks at the Alveolar Interface. Respir Physiol Neurobiol. 2010; 173:S55-S64. [PubMed: 20206718]

13. Lai P, Nathoo S, Ku T, Gill S, Azarmi S, Roa W, Lobenberg R, Prenner EJ. Real-Time Imaging of Interactions between Dipalmitoylphosphatidylcholine Monolayers and Gelatin Based Nanoparticles Using Brewster Angle Microscopy. J Biomed Nanotechnol. 2010; 6:145-152. [PubMed: 20738068]

14. Schleh C, Muhlfeld C, Pulskamp K, Schmiedl A, Nassimi M, Lauenstein HD, Braun A, Krug N, Erpenbeck VJ, Hohlfeld JM. The Effect of Titanium Dioxide Nanoparticles on Pulmonary Surfactant Function and Ultrastructure. Respir Res. 2009; 10:90. [PubMed: 19793393] 
15. Bakshi MS, Zhao L, Smith R, Possmayer F, Petersen NO. Metal Nanoparticle Pollutants Interfere with Pulmonary Surfactant Function in Vitro. Biophys J. 2008; 94:855-868. [PubMed: 17890383]

16. Harishchandra RK, Saleem M, Galla HJ. Nanoparticle Interaction with Model Lung Surfactant Monolayers. J R Soc Interface. 2010; 7:S15-S26. [PubMed: 19846443]

17. Beck-Broichsitter M, Ruppert C, Schmehl T, Guenther A, Betz T, Bakowsky U, Seeger W, Kissel T, Gessler T. Biophysical Investigation of Pulmonary Surfactant Surface Properties upon Contact with Polymeric Nanoparticles in Vitro. Nanomedicine. 2011; 7:341-350. [PubMed: 21059405]

18. Choe S, Chang R, Jeon J, Violi A. Molecular Dynamics Simulation Study of a Pulmonary Surfactant Film Interacting with a Carbonaceous Nanoparticle. Biophys J. 2008; 95:4102-4114. [PubMed: 18923102]

19. Schneemilch M, Quirke N. Molecular Dynamics of Nanoparticle Translocation at Lipid Interfaces. Mol Simul. 2010; 36:831-835.

20. Notter RH, Wang Z, Egan EA, Holm BA. Component-Specific Surface and Physiological Activity in Bovine-Derived Lung Surfactants. Chem Phys Lipids. 2002; 114:21-34. [PubMed: 11841823]

21. Zhang H, Fan Q, Wang YE, Neal CR, Zuo YY. Comparative Study of Clinical Pulmonary Surfactants Using Atomic Force Microscopy. Biochim Biophys Acta. 2011; 1808:1832-1842. [PubMed: 21439262]

22. Ong H, Loo J, Boey F, Russell S, Ma J, Peng KW. Exploiting the High-Affinity PhosphonateHydroxyapatite Nanoparticle Interaction for Delivery of Radiation and Drugs. J Nanopart Res. 2008; 10:141-150.

23. Loo SC, Siew YE, Ho S, Boey FY, Ma J. Synthesis and Hydrothermal Treatment of Nanostructured Hydroxyapatite of Controllable Sizes. J Mater Sci: Mater Med. 2008; 19:1389_ 1397. [PubMed: 17914615]

24. Loo SC, Moore T, Banik B, Alexis F. Biomedical Applications of Hydroxyapatite Nanoparticles. Curr Pharm Biotechnol. 2010; 11:333-342. [PubMed: 20199383]

25. Zhang H, Wang YE, Fan Q, Zuo YY. On the Low Surface Tension of Lung Surfactant. Langmuir. 2011; 27:8351-8358. [PubMed: 21650180]

26. Chen L, McCrate JM, Lee JC, Li H. The Role of Surface Charge on the Uptake and Biocompatibility of Hydroxyapatite Nanoparticles with Osteoblast Cells. Nanotechnology. 2011; 22:105708. [PubMed: 21289408]

27. Zhao X, Heng BC, Xiong S, Guo J, Tan TT, Boey FY, Ng KW, Loo JS. In Vitro Assessment of Cellular Responses to Rod-Shaped Hydroxyapatite Nanoparticles of Varying Lengths and Surface Areas. Nanotoxicology. 2011; 5:182-194. [PubMed: 21609137]

28. Possmayer F, Nag K, Rodriguez K, Qanbar R, Schurch S. Surface Activity in Vitro: Role of Surfactant Proteins. Comp Biochem Physiol, Part A: Mol Integr Physiol. 2001; 129:209-220.

29. Rodriguez-Capote K, Nag K, Schurch S, Possmayer F. Surfactant Protein Interactions with Neutral and Acidic Phospholipid Films. Am J Physiol. 2001; 281:L231-L242.

30. Veldhuizen RA, Yao LJ, Hearn SA, Possmayer F, Lewis JF. Surfactant-Associated Protein A Is Important for Maintaining Surfactant Large-Aggregate Forms during Surface-Area Cycling. Biochem J. 1996; 313:835-840. [PubMed: 8611163]

31. Veldhuizen RA, Ito Y, Marcou J, Yao LJ, McCaig L, Lewis JF. Effects of Lung Injury on Pulmonary Surfactant Aggregate Conversion in Vivo and in Vitro. Am J Physiol. 1997; 272:L872L878. [PubMed: 9176251]

32. Matsumoto T, Okazaki M, Inoue M, Yamaguchi S, Kusunose T, Toyonaga T, Hamada Y, Takahashi J. Hydroxyapatite Particles as a Controlled Release Carrier of Protein. Biomaterials. 2004; 25:3807-3812. [PubMed: 15020156]

33. Iafisco M, Sabatino P, Lesci IG, Prat M, Rimondini L, Roveri N. Conformational Modifications of Serum Albumins Adsorbed on Different Kinds of Biomimetic Hydroxyapatite Nanocrystals. Colloids Surf, B. 2010; 81:274-284.

34. Wright JR. Immunomodulatory Functions of Surfactant. Physiol Rev. 1997; 77:931-962. [PubMed: 9354809]

35. Li C, Liu H, Sun Y, Wang H, Guo F, Rao S, Deng J, Zhang Y, Miao Y, Guo C, et al. PAMAM Nanoparticles Promote Acute Lung Injury by Inducing Autophagic Cell Death through the AktTSC2-mTOR Signaling Pathway. J Mol Cell Biol. 2009; 1:37-45. [PubMed: 19516051] 
36. Inoue K, Takano H, Yanagisawa R, Hirano S, Kobayashi T, Fujitani Y, Shimada A, Yoshikawa T. Effects of Inhaled Nanoparticles on Acute Lung Injury Induced by Lipopolysaccharide in Mice. Toxicology. 2007; 238:99-110. [PubMed: 17614186]

37. Grommes J, Soehnlein O. Contribution of Neutrophils to Acute Lung Injury. Mol Med. 2011; 17:293-307. [PubMed: 21046059]

38. Quintero OA, Wright JR. Clearance of Surfactant Lipids by Neutrophils and Macrophages Isolated from the Acutely Inflamed Lung. Am J Physiol. 2002; 282:L330-L339.

39. Ng S, Guo J, Ma J, Loo SC. Synthesis of High Surface Area Mesostructured Calcium Phosphate Particles. Acta Biomater. 2010; 6:3772-3781. [PubMed: 20233611]

40. Zuo YY, Tadayyon SM, Keating E, Zhao L, Veldhuizen RA, Petersen NO, Amrein MW, Possmayer F. Atomic Force Microscopy Studies of Functional and Dysfunctional Pulmonary Surfactant Films, II: Albumin-Inhibited Pulmonary Surfactant Films and the Effect of SP-A. Biophys J. 2008; 95:2779-2791. [PubMed: 18539636]

41. Zuo YY, Keating E, Zhao L, Tadayyon SM, Veldhuizen RA, Petersen NO, Possmayer F. Atomic Force Microscopy Studies of Functional and Dysfunctional Pulmonary Surfactant Films. I. Microand Nanostructures of Functional Pulmonary Surfactant Films and the Effect of SP-A. Biophys J. 2008; 94:3549-3564. [PubMed: 18212010] 

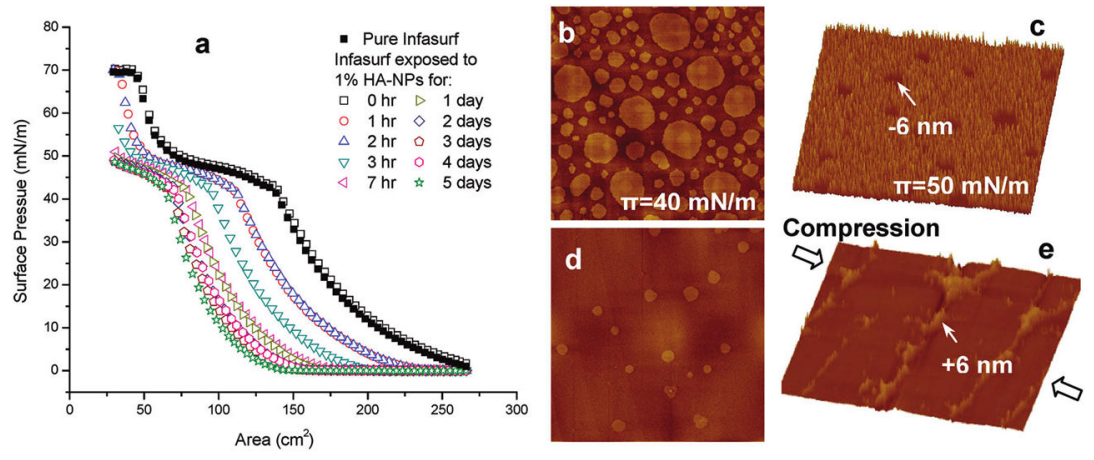

Figure 1.

Effect of $1 \mathrm{wt} \%$ hydroxyapatite nanoparticles (HA-NPs) on the compression isotherms (a) and interfacial structure (b-e) of a natural pulmonary surfactant film (Infasurf) as a function of exposure time to the particles. (a) Significant time-dependent shift of compression isotherms to the left after exposure to the HA-NPs, indicating surfactant inhibition, i.e., more area reduction is required to increasing surface pressure. $(b, c)$ AFM images of pure Infasurf at surface pressures $(\pi)$ of 40 and $50 \mathrm{mN} / \mathrm{m}$; (d,e) AFM images of Infasurf exposed to HANPs for $3 \mathrm{~h}$ at comparable surface pressures. The scan area of all AFM images was 50 - 50 $\mu \mathrm{m}$. The $Z$-range was $5 \mathrm{~nm}$ for (b) and (d) and $20 \mathrm{~nm}$ for (c) and (e). The comparison of lateral structure shows variations to domain formation in surfactant monolayers $(\mathrm{b} v \boldsymbol{d} \mathrm{d})$ and to organization of surfactant multilayers (c $v s$ e), due to exposure to HA-NPs. 

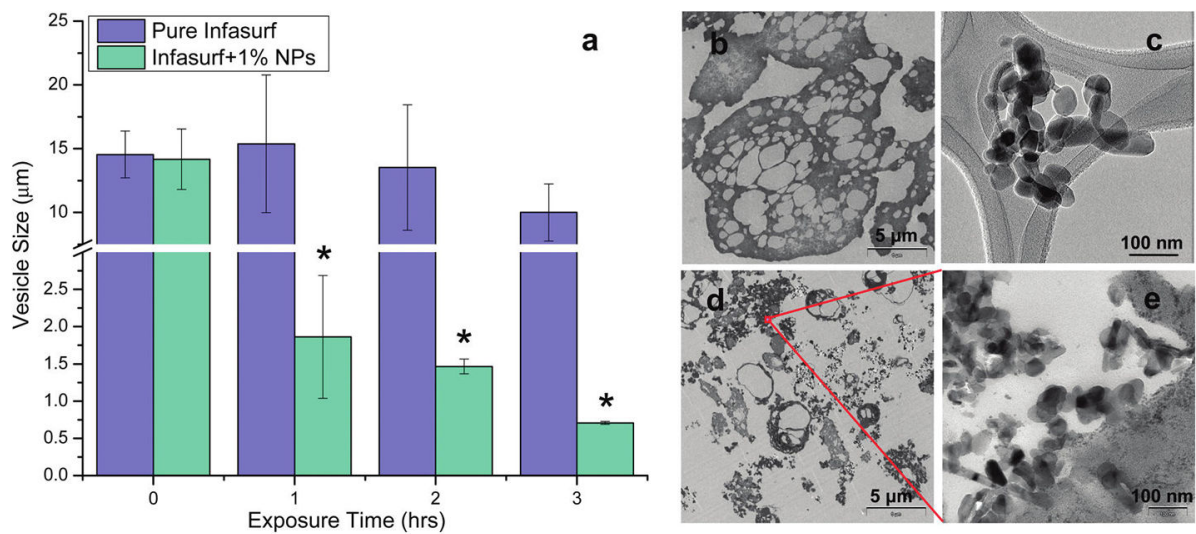

Figure 2.

Effect of $1 \mathrm{wt} \%$ hydroxyapatite nanoparticles (HA-NPs) on lipid vesicle size (a) and ultrastructure (b-e) of Infasurf as a function of exposure time to the particles. $(b, c)$ TEM images of pure Infasurf and bare HA-NPs, respectively. (d,e) TEM images of Infasurf exposed to HA-NPs for $3 \mathrm{~h}$. ${ }^{*} P<0.05$ for differences between Infasurf with and without HA-NPs. 

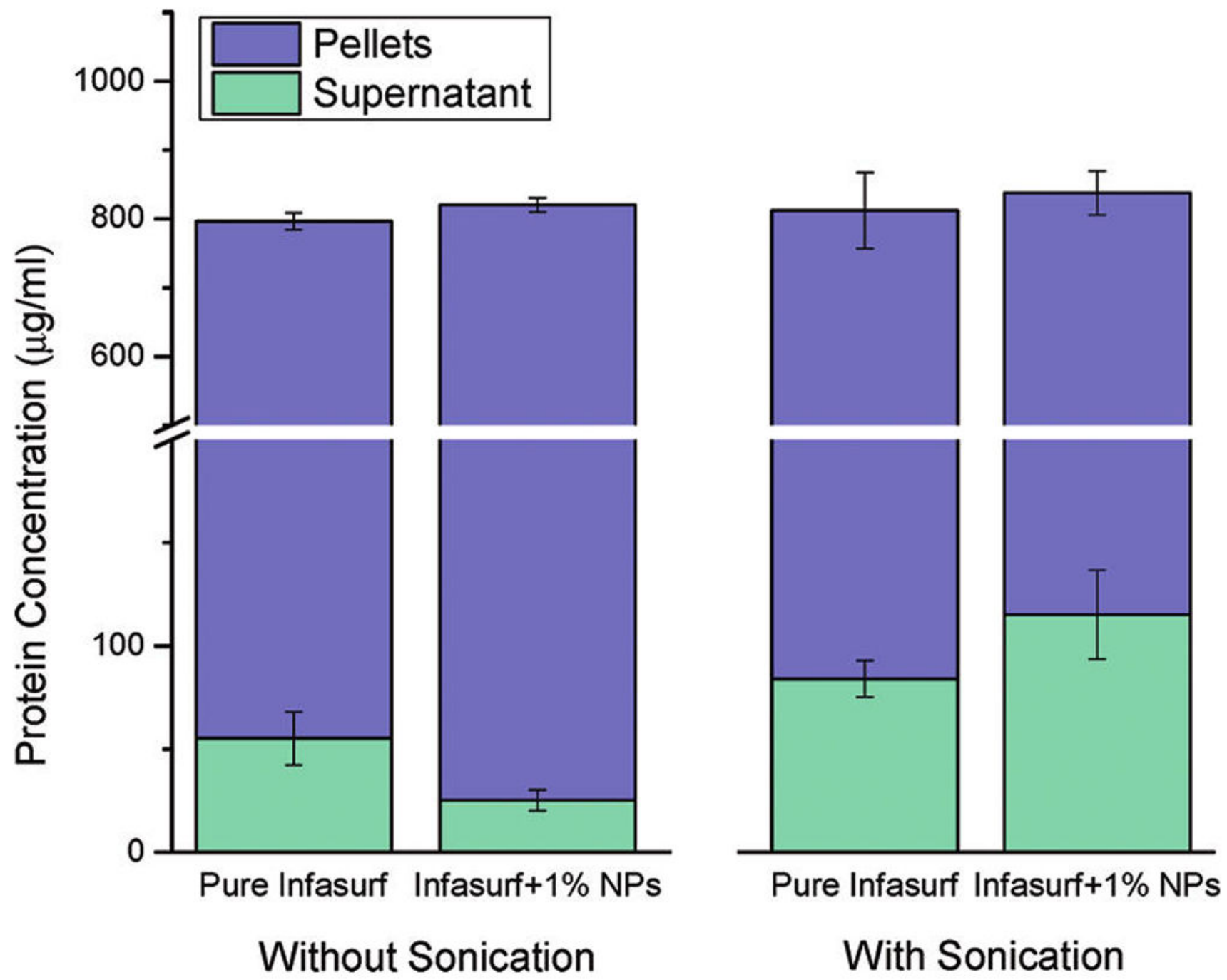

Figure 3.

Effect of $1 \mathrm{wt} \%$ hydroxyapatite nanoparticles (HA-NPs) on the distribution of surfactant proteins in supernatant and pellets. All samples were centrifuged at $25000 \mathrm{~g}$ for $15 \mathrm{~min}$, which spun down the lipids vesicles but not free NPs. Some samples were sonicated vigorously to break the binding between NPs and lipid vesicles. 


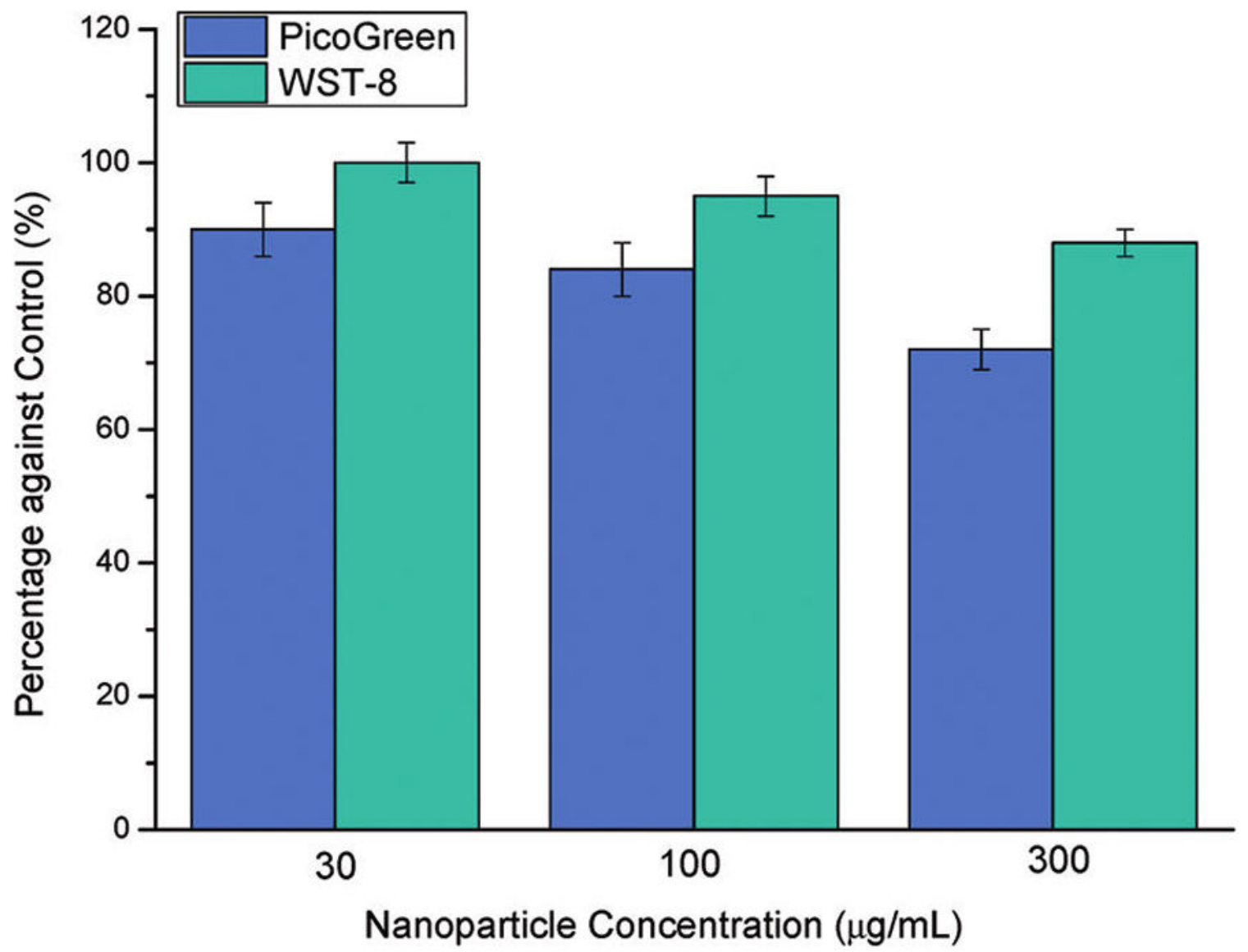

Figure 4.

Viability of BEAS-2B cells measured by total dsDNA content (PicoGreen) and metabolic activity (WST-8) expressed as percentage against control at HA-NP concentrations of 30, 100 , and $300 \mu \mathrm{g} / \mathrm{mL}(1 \mathrm{wt} \%=50 \mu \mathrm{g} / \mathrm{mL})$. 